Communications in Information Literacy

\title{
Do People Overestimate Their Information Literacy Skills? A Systematic Review of Empirical Evidence on the Dunning-Kruger Effect
}

Khalid Mahmood

University of the Punjab, khalidmahmood@yahoo.com

Follow this and additional works at: https://pdxscholar.library.pdx.edu/comminfolit

Let us know how access to this document benefits you.

\section{Recommended Citation}

Mahmood, K. (2016). Do People Overestimate Their Information Literacy Skills? A Systematic Review of Empirical Evidence on the Dunning-Kruger Effect. Communications in Information Literacy, 10 (2), 199-213. https://doi.org/10.15760/comminfolit.2016.10.2.24

This open access Research Article is distributed under the terms of the Creative Commons AttributionNonCommercial-ShareAlike 4.0 International License (CC BY-NC-SA 4.0). All documents in PDXScholar should meet accessibility standards. If we can make this document more accessible to you, contact our team. 


\title{
Do People Overestimate their Information Literacy Skills? A Systematic Review of Empirical Evidence on the Dunning- Kruger Effect
}

\author{
Khalid Mahmood, University of the Punjab
}

Abstract

This systematic review has analyzed 53 English language studies that assessed and compared peoples' self-reported and demonstrated information literacy (IL) skills. The objective was to collect empirical evidence on the existence of Dunning-Kruger Effect in the area of information literacy. The findings clearly show that this theory works in this area. It is concluded that there is no calibration in peoples' perceived and actual IL skills; in most cases low-performers overestimate their skills in self-assessments. The findings have theoretical and practical implications for librarians and IL educators.

Keywords: information literacy; assessment; Dunning-Kruger Effect

Mahmood, K. Do people overestimate their information literacy skills? A systematic review of empirical evidence on the Dunning-Kruger effect. Communications in Information Literacy, 10(2), 198-213.

Copyright for articles published in Communications in Information Literacy is retained by the author(s). Author(s) also extend to Communications in Information Literacy the right to redistribute this article via other scholarly resources and bibliographic databases. This extension allows the authors' copyrighted content to be included in some databases that are distributed and maintained by for-profit companies. All other rights of redistribution are licensed by Communications in Information Literacy under Creative Commons Attribution-NonCommercial-ShareAlike 4.0 International (CC BYNC-SA 4.0). 


\section{Do People Overestimate their Information Literacy Skills? A Systematic Review of Empirical Evidence on the Dunning- Kruger Effect}

\section{Introduction}

The assessment of self-perceptions has been one of the popular methods of evaluating information literacy skills of students and professionals. Self-efficacy, based on selfperceptions regarding particular behaviors, influences human functioning and is considered important for lifelong learning. Kurbanoglu, Akkoyunlu and Umay (2006) argued, "if individuals feel themselves competent and confident about the information literacy skills they will willingly undertake and easily solve information problems. Otherwise, it is more likely that they will avoid and hesitate to try solving information problems in their hands" (p. 731-732). From the point of view of educational psychology, self-assessment is a promising approach: "subjective ability is often considered a core belief that is the foundation of human motivation, performance accomplishments, and emotional well-being, and can therefore positively influence effort expenditure and task persistence, especially in the case of obstacles" (Rosman, Mayer \& Krampen, 2015, p. 742).

The literature on information literacy assessment repeatedly shows that self-reporting is not a substitute for the examination of people's actual information skills (Mahmood, 2013; Walsh, 2009). A major complaint against self-assessment is the lack of validity of this measure. The literature reported that people inflated their information skills: they were over confident in reporting their competencies compared to their actual performance. This behavior is referred to as Dunning-Kruger Effect.

The Dunning-Kruger Effect was proposed by Justin Kruger and David Dunning of Cornell University. They conducted four studies in the areas of humor, logical reasoning, and English grammar, in which they asked participants to self-assess their ability and test performance. The studies found that the lowest performing participants overestimated their own abilities and believed that their abilities were above-average. On the other hand, the highest performing participants underestimated their abilities. It was also found that incompetent individuals were less likely to recognize competence or expertise in others (Folk, in press). Based on the findings, Kruger and Dunning (1999) argued that people who 
were incompetent did not recognize their incompetence because they lacked metacognition, metamemory, metacomprehension, and self-monitoring skills. Dunning (2011) claimed that the poor performers face a double-curse:

...because the skills or knowledge they need to produce a correct response are often the very same ones they need to judge the quality of that response. For example, the expertise needed to produce logically sound arguments is exactly the same knowledge needed to recognize whether a person has just made a logically sound argument. Generating a valid physics proof requires the same math skills needed to check the validity of the proof. (p. 152)

Various studies substantiated the Dunning-Kruger Effect in many subject areas. For instance, the overestimating behavior was evident in university students' logical reasoning ability, specialist physicians' clinical practice, and salesmen's ability to sell (Hubka, 2015). The landmark study of Kruger and Dunning (1999) has been widely quoted by subsequent literature on the subject.

In the area of information literacy, Gross and Latham $(2007,2009,2012)$ replicated the research of Dunning and Kruger; in two out of three studies, they identified a disconnect between students' self-assessments of their information literacy skills and their actual skill level. Other studies also compared peoples' self-reported IL skills and their actual performance, but the existence of Dunning-Kruger Effect has been inconclusive. For example, Rosman, Mayer and Krampen (2015) were of the view that, "although a few studies have been conducted on the subject in information literacy research, no final conclusion on the validity of information literacy self-assessments can be drawn yet" (p. 743).

The objective of the current study is to systematically collect and review the English language studies that provided empirical evidence for the existence or non-existence of Dunning-Kruger Effect in the assessment of peoples' information literacy skills. Specifically, the study addressed the following question: Does Dunning-Kruger Effect exist in studies that collected and compared peoples' perceived and actual information literacy skills? 


\section{Method}

This review was performed following the preferred reporting items for systematic reviews and meta-analyses (PRISMA) guidelines (Shamseer et al., 2015).

\section{Search strategy}

A systematic search of literature was carried out with the following search strategy:

("information skills" OR "information competencies" OR "information literacy" OR "library literacy” OR "library instruction” OR "bibliographic instruction”)

\section{AND}

\section{(survey OR assessment OR evaluation OR test)}

A search was performed in two specialized databases-i.e., Library and Information Science Abstracts (LISA) and Library, Information Science \& Technology Abstracts (LISTA)-and three general databases-i.e., Web of Science (WoS), Scopus, and Google Scholar-using the library portal at University of Dammam, Saudi Arabia in November 2015. The search was updated in March 2016. A manual search was also carried out based on review articles and a few key studies. It included a backward and forward citation search in Google Scholar.

\section{Inclusion and exclusion criteria}

The eligible studies for this review included those that assessed and compared peoples' selfreported information skills and their actual knowledge or skills. There was no limit applied for the year of publication, or for type of document. Therefore, journal articles, book chapters, conference papers, dissertations, reports, etc. were included. Studies reporting assessment of all types of participants (students, professionals, etc.) were included. However, only English language studies were selected.

\section{Mahmood \\ Do People Overestimate IL Skills}


Figure 1 - Four-phase flow diagram of the selection procedure of studies

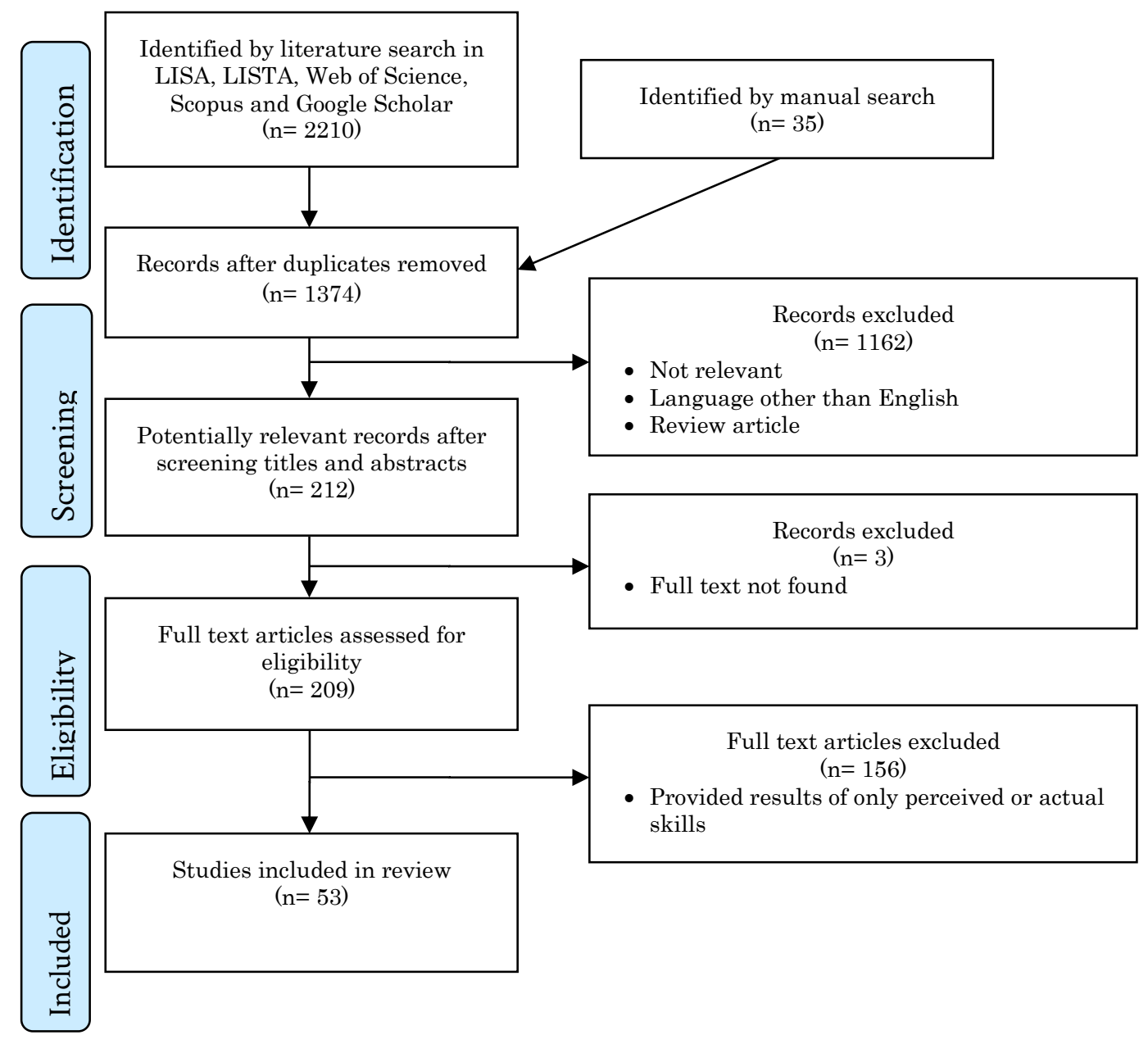

Study selection and data extraction

The flow chart in Figure 1 shows the process of screening and selection of eligible studies and reasons for exclusion. The two stages of screening-i.e., title/abstract and full textresulted in the selection of 53 studies for inclusion in this review. A data extraction form was completed for each eligible study to collect information on the name of first author, publication year, characteristics of sample, method of assessing self-reported skills, method of assessing actual skills, and findings regarding Dunning-Kruger Effect. 


\section{Results}

\section{Overview of studies}

A search in five databases and a manual search yielded a total of 2,245 documents, of which the author collected and scanned 209 full text documents after an initial scanning of titles and abstracts. Fifty-three studies met the inclusion criteria with results of comparison between participants' self-reported information skills and their actual knowledge or skills. Table 1 (provided as a supplement to this article) shows a summary of the data extracted from the selected studies. The year of publications ranged between 1986 and 2015. Most of the researches were published in library and information science journals, but some were published in the literature of other fields. Thirty-three studies were conducted in USA. Research conducted in other countries included UK (7 studies), Australia (5 studies), Canada (2 studies), and one study each in New Zealand, Belgium, Malaysia, Norway, Germany and the Netherlands. The participants in 50 studies were current students. Participants of the remaining three studies were medical practitioners; volunteers from financial, retail, consulting, and distribution sectors; and past students. In most cases, the participants were undergraduates, and in many cases they were newly admitted undergraduate students. Participants belonged to various subject areas of pure, applied, and social sciences; represented fields included medicine, nursing, biology, psychology, engineering, business, law, education, and management information systems. The sample sizes ranged between 15 and 2,114 participants.

The studies under review used various methods to assess self-reported information skills of the participants. The most popular was a questionnaire survey. In most cases, the researchers used locally designed questionnaires. In some studies, well-known instruments were used: e.g., the Research Readiness Self-Assessment (RRSA) tool, the Information Literacy Self-Efficacy scale, etc. A few studies used interviews to collect such data. Interestingly, there is more variety in the methods of assessing actual knowledge or skills of the participants. These methods include open-ended paper-and-pencil and online tests, multiple choice question (MCQ)-based tests/questionnaires, observations, field notes, participant reflexive journals, expert grading of searching tasks, analysis of students' theses, quizzes, and information related assignments.

\section{Evidence on Dunning-Kruger Effect}

In 34 studies (64\%) the evidence clearly showed that the participants overestimated their self-reported IL skills compared to their actual skills. In seven other studies (13\%) a partial 
evidence of overconfidence was available. On the other hand, two studies (4\%) fully and three studies (6\%) partially provided evidence that the participants underestimated their skills. Only four studies (8\%) showed a positive correlation between perceived and actual skills, while another group of four studies (8\%) showed this correlation partially. This means there was a match between two types of assessment. Five studies (9\%) found weak (statistically insignificant) or no correlation between self-reported and actual skills. The direction of discrepancy (over or under) was not evident in these cases. An overall evidence of inconsistency (overestimated, underestimated, weak correlation, no correlation) was found in 49 (full or partial) out of 53 studies (92\%).

Medicine (an applied science) and business (a social science) were the largest subject groups in this review. A subject analysis of the evidence of Dunning-Kruger Effect shows that this behavior was found in six of nine medicine-related studies while it was found in seven of eight business-related studies. Based on this finding, we may infer that the overestimation behavior was greater in social science participants. Overestimation behavior was found in 31 of 37 studies on undergraduates; conversely, only one study on graduate students fully and another partially reported overestimation of IL skills. From this, we may infer that the higher academic level positively influences the accuracy of students' assessment of their own IL skills.

\section{Discussion}

The current study is the first of its kind in the area of information literacy. The results based on 53 studies clearly reveal that the Dunning-Kruger Effect exists as it relates to peoples' information literacy skills. The analyzed studies came from a variety of geographical and subject areas and were conducted on different age groups. The findings substantiate the notion that people generally inflate their perceived level of skills in a particular domain. There is no match between self-efficacy and actual performance. Ninety-two percent of the cases presented should be considered as ample evidence to conclude the debate on DunningKruger Effect in the area of information skills.

Collection and analysis of a large amount of evidence in this study may have implications for both theory and practice. The first implication is that these findings pose an important question on the validity of self-assessment of IL skills. Latham and Gross (2008) have already suggested that "in terms of information literacy, confidence is not a reliable 
predictor of competence" (p. 11). Information literacy practitioners may include subjective approaches to their test batteries, but they cannot rely solely on these measures.

Another implication of Dunning-Kruger Effect is that the "individuals with belowproficient skills are unlikely to seek remediation for skills they believe they have, and that because they have a high level of confidence in their ability, they are unlikely to seek help, even when their attempts at finding information fail or result in low-quality information or partial answers" (Gross \& Latham, 2012, p. 574). They will not have any motivation to join IL training, or they may be disengaged from classes.

There is a general perception in society that the "Google generation," with their computing and Internet skills, are also information literate. The research on this subject has found that "this assertion was a 'dangerous myth.' Digital familiarity and information literacy could not be equated, and there was no apparent evidence of an improvement (or particularly of a deterioration) of young people's information skills” (Bates, 2013, p. 176). They must be taught such skills.

Findings of the current study warrant further research in the area of IL assessment. Specifically, preliminary indications of differences in the Dunning-Kruger Effect between applied sciences and social sciences, and between undergraduates and graduates, lead to formulate hypotheses to be tested. The author is suggesting here a few questions to be answered in future studies:

1. Which IL assessment techniques are being used? In which frequency? With how much accuracy of measuring actual IL skills?

2. What is the difference in the magnitude of Dunning-Kruger Effect in different cohorts based on age, gender, subject area, academic level, profession, cultural background, and frequency of already attended IL training programs?

3. Is the level of Dunning-Kruger Effect different in various components of information literacy?

4. Are librarians and IL decision-makers aware of the problem of Dunning-Kruger Effect? To what extent they consider this phenomenon in planning IL programs?

5. What special measures IL program planners take to motivate and involve 'lowachievers' of IL skills in training programs? 


\section{Limitations}

Although this systematic review was rigorous, the search was limited to the English language studies. There may be informative studies published in other languages that were missed in this review. Two major abstracting databases from the library and information science field and three general indexing and citation databases were used, and a large number of documents were scanned to maximize the search; however, some relevant studies may have been overlooked. Furthermore, the nature of systematic reviews like this reflects the shortcomings of the studies reviewed; included studies were heterogeneous in terms of the methods of data collection and analysis. Various definitions of information literacy skills were used: i.e., ACRL or other standards, IT skills, ICT skills, basic computing skills, assignment writing skills, research skills, etcetera. Terms of "knowledge" and "skill" were sometimes used differently and sometimes interchangeably. Similarly, overestimating of self-assessment was reported differently in studies: i.e., overconfidence, high level of comfort, over-assumption of performance in IL test, overrating the quality of searching techniques/sources found, et cetera.

\section{Conclusion}

This systematic review analyzed studies that assessed peoples' self-reported and actual information literacy skills. The objective was to collect empirical evidence on the existence of Dunning-Kruger Effect. The findings clearly show that this theory can be applied in the area of information literacy. Based on the results, we can conclude with more confidence that there is little calibration in peoples' perceived and actual IL skills. In most of the cases, low-performers overestimate their skills in self-assessments. These findings have implications for theory and practice. As self-efficacy scales are not reliable instruments to assess IL skills, knowledge and skill tests and practical assignments may be used for the important task of IL assessment. Librarians and IL educators should also design training programs to look after the needs of low-achievers. Further studies are also needed to explore the existence and impact of Dunning-Kruger Effect in different cohorts. 


\section{References}

Bandyopadhyay, A. (2013). Measuring the disparities between biology undergraduates' perceptions and their actual knowledge of scientific literature with clickers. Journal of Academic Librarianship, 39(2), 194-201.

Bates, D. (2013). Are 'Digital natives' equipped to conquer the legal landscape? Legal Information Management, 13(3), 172-178.

Black, N. E. (2014). The information seeking experiences of the post-secondary distance/online student (Unpublished doctoral dissertation). University of British Columbia, Vancouver, Canada.

Boucher, C., Davies, M., Glen, S., Dalziel, K., \& Chandler, J. (2009). Are postgraduates ready for research? Poster presented at LILAC Conference, Cardiff, UK, March 2009.

Retrieved from http://rrsa.cmich.edu/documents/RRSA_poster_LILAC_2009.pdf

Brown, M., \& Turnbow, D. (2009). Actual \& perceived information literacy skills in preservice educators. Retrieved from http://libraries.ucsd.edu/bmcl/dturnbow/finalpaper_brown_turnbow.pdf

Caspers, J., \& Bernhisel, S. M. (2005). What do freshmen really know about research? Assess before you teach. Research Strategies, 20(4), 458-468.

Coombes, B. (2009). Generation Y: Are they really digital natives or more like digital refugees. Synergy, 7(1), 31-40.

Craig, A., \& Corrall, S. (2007). Making a difference? Measuring the impact of an information literacy programme for pre-registration nursing students in the UK. Health Information \& Libraries Journal, 24(2), 118-127.

Cullen, R., Clark, M., \& Esson, R. (2011). Evidence-based information-seeking skills of junior doctors entering the workforce: An evaluation of the impact of information literacy training during pre-clinical years. Health Information $\&$ Libraries Journal, 28(2), 119-129.

De Meulemeester, A., \& Buysse, H. (2014). Progress testing of information literacy versus information literacy self-efficacy in medical students. In S. Kurbanoglu et al. (Eds.), Information literacy. lifelong learning and digital citizenship in the 21st century (pp. 361-369). Springer International Publishing. 
Dunning, D. (2011). The Dunning-Kruger Effect: On being ignorant of one's own ignorance. In J. Olson and M. P. Zanna (Eds.), Advances in experimental social psychology (vol. 44, pp. 247-296). New York: Elsevier.

Dunning, D. (2015). On identifying human capital: Flawed knowledge leads to faulty judgments of expertise by individuals and groups. In S. R. Thye and E. J. Lawler (Eds.), Advances in group processes (pp. 149-176). Emerald Group Publishing.

Easton, G., \& Easton, A. (2003). Assessing computer literacy: A comparison of selfassessment and actual skills. In T. McGill (Ed.), Current issues in IT education (pp. 238254). Hershey, PA: IRM Press.

Ferguson, J. E., Neely, T. Y., \& Sullivan, K. (2006). A baseline information literacy assessment of biology students. Reference \& User Services Quarterly, 46(2), 61-71.

Fischhoff, B., \& MacGregor, D. (1986). Calibrating databases. Journal of the American Society for Information Science, 37(4), 222-233.

Folk, A. (2016). Academic self-efficacy, information literacy, and undergraduate courserelated research: Expanding Gross's Imposed Query Model. Journal of Library Administration, 56(5), 540-558.

Ganley, B. J., Gilbert, A., \& Rosario, D. (2013). Faculty and student perceptions and behaviours related to information literacy: A pilot study using triangulation. Journal of Information Literacy, 7(2), 80-96.

Geffert, B., \& Christensen, B. (1998). Things they carry: Attitudes toward, opinions about, and knowledge of libraries and research among incoming college students. Reference $\mathcal{E}$ User Services Quarterly, 37(3), 279-289.

Grant, D. M., Malloy, A. D., \& Murphy, M. C. (2009). A comparison of student perceptions of their computer skills to their actual abilities. Journal of Information Technology Education, 8(1), 141-160.

Gravill, J. I., Compeau, D. R., \& Marcolin, B. L. (2006). Experience effects on the accuracy of self-assessed user competence. Information \& Management, 43(3), 378-394.

Greer, A., Weston, L., \& Alm, M. (1991). Assessment of learning outcomes: A measure of progress in library literacy. College \& Research Libraries, 52(6), 549-557. 
Gross, M. (2005). The impact of low-level skills on information-seeking behavior: Implications of competency theory for research and practice. Reference \& User Services Quarterly, 45(2), 155-162.

Gross, M., \& Latham, D. (2007). Attaining information literacy: An investigation of the relationship between skill level, self-estimates of skill, and library anxiety. Library $\mathcal{E}$ Information Science Research, 29(3), 332-353.

Gross, M., \& Latham, D. (2009). Undergraduate perceptions of information literacy: Defining, attaining, and self-assessing skills. College $\&$ Research Libraries, 70(4), 336-350.

Gross, M., \& Latham, D. (2012). What's skill got to do with it? Information literacy skills and self-views of ability among first-year college students. Journal of the American Society for Information Science and Technology, 63(3), 574-583.

Gustavson, A., \& Nall, H. C. (2011). Freshman overconfidence and library research skills: A troubling relationship? College \& Undergraduate Libraries, 18(4), 291-306.

Guy, R. S., \& Lownes-Jackson, M. (2010). An examination of students' self-efficacy beliefs and demonstrated computer skills. Issues in Informing Science and Information Technology, 7, 285-295.

Hollern, K., \& Carrier, H. S. (2014). The effects of library instruction on the legal information research skills of students enrolled in a legal assistant studies program. Georgia Library Quarterly, 51(4), 1-26.

Holman, L. (2000). A comparison of computer-assisted instruction and classroom bibliographic instruction. Reference \& User Services Quarterly, 40(1), 53-60.

Hubka, T. N. (2015). The capability to align estimated performance with actual performance: Insights from physical \& cognitive performance contexts (Unpublished master's thesis). The University of Sydney, NSW, Australia.

Ivanitskaya, L., O’Boyle, I., \& Casey, A. M. (2006). Health information literacy and competencies of information age students: Results from the interactive online Research Readiness Self-Assessment (RRSA). Journal of Medical Internet Research, 8(2), 1-14.

Jackson, C. (2013). Confidence as an indicator of research students' abilities in information literacy: a mismatch. Journal of Information Literacy, 7(2), 149-152.

\section{Mahmood \\ Do People Overestimate IL Skills}


Kruger, J., \& Dunning, D. (1999). Unskilled and unaware of it: How difficulties in recognizing one's own incompetence lead to inflated self-assessments. Journal of Personality and Social Psychology, 77(6), 1121-1134.

Kurbanoglu, S. S., Akkoyunlu, B., \& Umay, A. (2006). Developing the information literacy self-efficacy scale. Journal of Documentation, 62(6), 730-743.

Lai, N. M., \& Teng, L. C. (2011). Self-perceived competence correlates poorly with objectively measured competence in evidence based medicine among medical students. BMC Medical Education, 11(1), 1-8.

Latham, D., \& Gross, M. (2008). Broken links: Undergraduates look back on their experiences with information literacy in K-12 education. School Library Media Research, 11, 1-17.

Leeder, C. A. (2014). Scaffolding students' information literacy skills with an online credibility evaluation learning tool (Unpublished doctoral dissertation). University of Oklahoma, Norman.

Mahmood, K. (2013). Relationship of students' perceived information literacy skills with personal and academic variables. Libri, 63(3), 232-239.

Maughan, P. D. (2001). Assessing information literacy among undergraduates: A discussion of the literature and the University of California-Berkeley assessment experience. College E Research Libraries, 62(1), 71-85.

McCourt Larres, P., Ballantine, J., \& Whittington, M. (2003). Evaluating the validity of selfassessment: Measuring computer literacy among entry-level undergraduates within accounting degree programmes at two UK universities. Accounting Education, 12(2), 97112.

McKeever, C. M. (2013). Information literacy skills in year 14 school leaving pupils - Are they ready for third level study? Journal of Information Literacy, 7(1), 99-106.

Merritt, K., Smith, D., \& Renzo, J. C. D. (2005). An investigation of self-reported computer literacy: Is it reliable. Issues in Information Systems, 6(1), 289-295.

Molteni, V. E., \& Chan, E. K. (2015). Student confidence/overconfidence in the research process. The Journal of Academic Librarianship, 41(1), 2-8. 
Monoi, S., O’Hanlon, N., \& Diaz, K. R. (2005). Online searching skills: Development of an inventory to assess self-efficacy. Journal of Academic Librarianship, 31(2), 98-105.

Nierenberg, E., \& Fjeldbu, Ø. G. (2015). How much do first-year undergraduate students in Norway know about information literacy? Journal of Information Literacy, 9(1), 15-33.

O'NEIL, P. M. B. (2005). Development and validation of the Beile Test of Information Literacy for Education (B-TILED) (Unpublished doctoral dissertation). University of Central Florida, Orlando).

Oliver, B. (2008). Commencing undergraduates' self-efficacy and ability in finding academic resources: Are they improving? Studies in Learning, Evaluation, Innovation and Development, $5(3), 1-8$.

Perrett, V. (2004). Graduate information literacy skills: The 2003 ANU skills audit. The Australian Library Journal, 53(2), 161-171.

Price, R., Becker, K., Clark, L., \& Collins, S. (2011). Embedding information literacy in a first-year business undergraduate course. Studies in Higher Education, 36(6), 705-718.

Ren, W. H. (2000). Library instruction and college student self-efficacy in electronic information searching. Journal of Academic Librarianship, 26(5), 323-328.

Robertson, D. S., \& Felicilda-Reynaldo, R. F. D. (2015). Evaluation of graduate nursing students' information literacy self-efficacy and applied skills. Journal of Nursing Education, 54(3), S26-S30.

Rosman, T., Mayer, A-K., \& Krampen, G. (2015). Combining self-assessments and achievement tests in information literacy assessment: Empirical results and recommendations for practice. Assessment \& Evaluation in Higher Education, 40(5), 740-754.

Ross, M., Fosmire, M., Wertz, R. E., Cardella, M., \& Purzer, S. (2011). Lifelong learning and information literacy skills and the first year engineering undergraduate: Report of a selfassessment. Retrieved from http://docs.lib.purdue.edu/cgi/viewcontent.cgi?article=1067\&context=lib_fsdocs

Schilling, K., \& Applegate, R. (2007). Evaluating library instruction: Measures for assessing educational quality and impact. Paper presented at ACRL Thirteenth National Conference, March 29-April 1, 2007, Baltimore, Maryland. Retrieved from https://www.researchgate.net/profile/Katherine_Schilling/publication/228604499_Eval 
uating_library_instruction_measures_for_assessing_educational_quality_and_impact/lin ks/00b49534eb2356c644000000.pdf

Schroeter, C., \& Higgins, L. (2015). The impact of guided vs. self-directed instruction on student's information literacy skills. Journal for Advancement of Marketing Education, 23(1), $1-10$.

Shamseer, L., Moher, D., Clarke, M., Ghersi, D., Liberati, A., Petticrew, M., ... \& Stewart, L. A. (2015). Preferred reporting items for systematic review and meta-analysis protocols (PRISMA-P) 2015: Elaboration and explanation. BMJ, 349, g7647.

Swartz, B., Ratcliff, A., \& Ivanitskaya, L. (2015). Correlation of attitudes and beliefs with actual abilities of speech-language pathology students regarding aspects of information literacy. Contemporary Issues in Communication Science \& Disorders, 42, 215-225.

Tepe, R., \& Tepe, C. (2015). Development and psychometric evaluation of an information literacy self-efficacy survey and an information literacy knowledge test. Journal of Chiropractic Education, 29(1), 11-15.

Timmers, C. F., Walraven, A., \& Veldkamp, B. P. (2015). The effect of regulation feedback in a computer-based formative assessment on information problem solving. Computers $\mathcal{E}$ Education, 87, 1-9.

Varga-Atkins, T., \& Ashcroft, L. (2004). Information skills of undergraduate business students - a comparison of UK and international students. Library Management, 25(1/2), 39-55.

Vickery, S., \& Cooper, H. (2003). Confidence or competence? Auditing information literacy skills of biology undergraduate students. Paper presented at EDUCAUSE in Australasia 03:

Expanding the learning community, meeting the challenges 6-9 May, 2003 Adelaide, South Australia. Retrieved from http://www.researchonline.mq.edu.au/vital/access/services/Download/mq:828/DS01

Walsh, A. (2009). Information literacy assessment: Where do we start? Journal of Librarianship and Information Science, 41(1), 19-28.

Weisskirch, R. S., \& Silveria, J. B. (2005). The effectiveness of project-specific information competence instruction. Research Strategies, 20(4), 370-378. 